\title{
THE USE OF DIALOGIC READING IN READING ACTIVITY BY IMPLEMENTING CHARACTER BUILDING USING LOCAL BASED LITERATURE
}

\author{
Puji Astuti Amalia (ib) ${ }^{1)}$ dan Arditiya (i) $)^{2}$ \\ ${ }^{1}$ Teknika, Politeknik Negeri Samarinda \\ ${ }^{2}$ Nautika, Politeknik Negeri Samarinda \\ ${ }^{1,2}$ Dr. Cipto Mangunkusumo, Samarinda, 75131 \\ E-mail : Pujiastutiamalia@ polnes.ac.id ${ }^{1)}$, arditiya.mitra@ polnes.ac.id ${ }^{2)}$
}

\begin{abstract}
Reading is considered as one of the most important skill in learning foreign language since it is used in all language skills. However, teaching reading is quite challenging. In Permata group, young learners seem not motivated in reading activity. Pre observation showed that learners were bored during the shared reading activity. Moreover there were no interaction during the activity. Therefore, it takes teacher's creativity and innovation to teach reading. This situation led the teacher to a new way of teaching reading, the teacher implemented a new approach in teaching reading by using dialogic reading. Moreover, the literature used by the teacher was a local based short story with the theme "Save Mahakam". This study is a qualitative study in which the data was collected by observation and questionnaire. The study found that the dialogic reading and the short story did not only make the reading activity more interesting but they also helped the teachers to shape young learners' characters. It found that there were some characters developed through the process of reading activity, such as 1) young learners have courage to speak, 2) young learners are friendly and sociable, 3) young learners are responsible with the environment, 4) young learners love reading, 5) young learners work in a team, 6) young learners think critically.
\end{abstract}

Keywords: Reading, Dialogic Reading, Character Building.

\section{INTRODUCTION}

Studies show that reading is a very important aspect of learning and acquiring information (Farzaneh and Nejadansari, 2014). The more young learners is exposed to reading aloud activity, the larger their vocabulary is. Furthermore, the vocabulary skill helps the young learners to build important skills such as literacy and social skills. A study proofed that reading books for young learners has been shown to be very helpful in improving vocabulary, communication and memory skills (Sim and Berthelsen, 2014).

Therefore, it is very important to motivate young learners to read. However, learners who learn foreign languages, especially English, still are not motivated enough in reading activity. The study of PISA showed that reading competency in Indonesia is in the position of 50 out of 72 countries (Nugrahanto and Zuchdi, 2019). Furthermore, a study explained that the poor reading comprehension occurred due to the following reasons, including the learners' lack of motivation in reading, the low of prior knowledge and the poor of English vocabulary (Nanda and Azmy, 2020). It is a serious issue that need to be solved. In other words, it needs creativity and innovation from the teacher to teach reading using an effective and attractive method so that young learners were motivated in reading activity.
Besides the issue of reading comprehension itself, it is also important to develop young learners' characters. young learners need to learn about the quality of a good character. It can be done through the reading activity using a high quality literature (Almerico, 2014). In short, building young learners character can be done through the use of literacy.

Studies have found that dialogic reading is an effective activity to improve reading skills (Ping, 2014). Dialogic reading itself is a reading activity in a small group of young learners accompanied by adult using a set of technique in the reading process. Furthermore, study also found that dialogic reading facilitates learners with the socioemotional development in which learner can acquire some skills, including team work to develop relationship with others. Therefore, dialogic reading can support the implementation of character-building learning.

Based on the pre-observation, it was found that teaching reading or having shared reading activity in a Permata Group (Samarinda) was quite challenging. Young learners were not motivated by the book and the reading stages. Learners were not excited during the reading activity. Moreover, there were no interactions during the activity. This study aims to apply dialogic reading to increase young learners' interest in reading and to shape learner characters. 


\section{FOCUS AND SCOPE}

The subjects of this study were the students in Permata Group (Samarinda). This research eagers to know what are the learners' characters that can be developed through teaching reading using dialogic reading and the local short story.

\section{MATERIAL AND METHOD}

This subtopic contains the literature review and the methodology of this study.

\subsection{Reading}

Reading is one of the basic skills. It is the process of obtaining information. Therefore, reading tends to be related to academic success (Farzaneh and Nejadansari, 2014). Moreover reading can help learners acquire new vocabulary (You, 2011). Lack of vocabulary leads to inability of children to comprehend the texts. It also may cause problems in social behaviour. Therefore, the importance of mastering vocabulary for children at an early age should be a consideration for teachers to be able to provide more intervention or attention in improving the vocabulary skills of early childhood. Meanwhile, foreign language teachers or teachers can support children to improve their vocabulary through reading activities using appropriate methods. The method that can be used to overcome this problem is through dialogic reading.

\subsection{Dialogic Reading}

Dialogic reading is a form of reading activity through dialogue between adult and young learner in a small group. Dialogic reading is good for young learners since it can increase young leaners' interest in reading activity, help them acquire new vocabulary, and improve their language development (Lonigan CJ, Purpura DJ, Wilson SB, Walker PM, 2013; Ping, 2014). In dialogic reading, there is an interaction between teachers, young learners and book. This interaction involves dialogue or participation from young learners during reading activities. The procedures used by teacher that encourage children to participate are PEER (prompt, evaluate, expand, and repeat) and CROWD (completion questions, recall questions, open-ended questions, wh- questions, and distancing).

PEER is a set of technique used by teacher, they are: (1) the teacher encourages young learners to say something about the book that is being read, (2) the teacher evaluates the young learners' response, (3) the teacher evaluates the young learners' answer and expands the child's response by confirming and adding information to it if the young learners' answer is not correct, and (4) the teacher asks the young learners to repeat the correct answer to make sure the child has learned from the expansion.

CROWD is an effort encourage young learners to talk in order to get them involved in reading activities. For example, by asking WH-questions may help young learners learn new words and phrases. Open-ended questions also give young learners the opportunity to use new vocabulary or phrase. Furthermore, the teacher will provide feedback on the words spoken by the young learners. There are five types of prompts used in dialogic reading. They are:

1. The teacher makes incomplete sentences and encourages the young learners to complete the sentence

2. The teacher makes the young learners remember the information in the book, such as "do you still remember what happened to the cat?"

3. The teacher makes open questions "tell me about this picture"

4. The teacher points to something in the picture and asks the young learners to name the objects or activities in the picture by making questions starting with WH (who, what, when, where, why, how) for example, "why was the cat sad?"

5. The teacher makes the children connect the pictures or words in the book with the daily experiences experienced by the children. "Do you usually feed your cat at home?".

\subsection{Character Building}

One of the reasons for character building should be integrated in learning activity or education is that because education is the effective way to implement and develop ones' character. In the early stage character is developed in family, then school and environment. Character building should not only be integrated in formal education inside the classroom but also in informal education such as in learning club.

Moreover, Character is defined as attitude, behaviour, motivation, and skill (Gunawan, 2012). Furthermore, there are 18 values that contribute to character building such as religious, honest, tolerance, discipline, hard work, creative, independent, democratic, curious, responsible, friendly and communicative, have spirit of nationalism, love the country, appreciate achievement, like reading, care with the environment, care with others

\subsection{Methodology}

This study is a qualitative study. The data was collected through observation, questionnaire and interview. The data is explained by using verbal description instead of numerical. This study used descriptive explanation to find out the learners' characters developed through reading activity. The subject in this study was a group of young learners in a study club which consists of 10 learners in the age of 10 -11 years old. Before the study was conducted, pre investigation was carried on. Pre study found that young learners were not motivated in reading activity moreover it was found that learners were quite boring with the previous reading activity. Therefore, this study was 
conducted and the young learners were taken as the subject in this study.

There are some instruments used in this study. The first was questionnaire. The questionnaire used in this study to find out how the young learners respond to the reading activity. Questionnaire is a set of questions or statements in a written form distributed in order to learn about the distribution of characteristics, attitudes, or beliefs. The questionnaire used Likert scale and analyzed by five indicators, strongly agree, agree, no idea, disagree, and strongly disagree. The score of each item was summed up.

The second instrument was interview guideline. Young learners who got the highest score and the lowest on the questionnaire were interviewed by using a set of questions that were prepared before the interview session and the questions were developed during the interview. The interview was analyzed and explained qualitatively (Creswell, 2014). It was analyzed by using three activities, they are data reduction, data display, and conclusion drawing. In order to increase the validity of the finding the data was triangulated by using data triangulation and theory triangulation (Lisa A. Guion, David C. Diehl, 2011). Interview session with the teacher was used as the data triangulation while theory related to dialogic reading was used as theory triangulation.

\section{DISCUSSION}

The result of the questionnaire showed that Adhar was a student who got the highest score, Jannah got the average score and Riza got the lowest score on the questionnaire. These three students were interviewed to find more information about the process of character building during the reading activity.

The interview found that there were some characters developed through the dialogic reading activity as can be seen in figure 1.

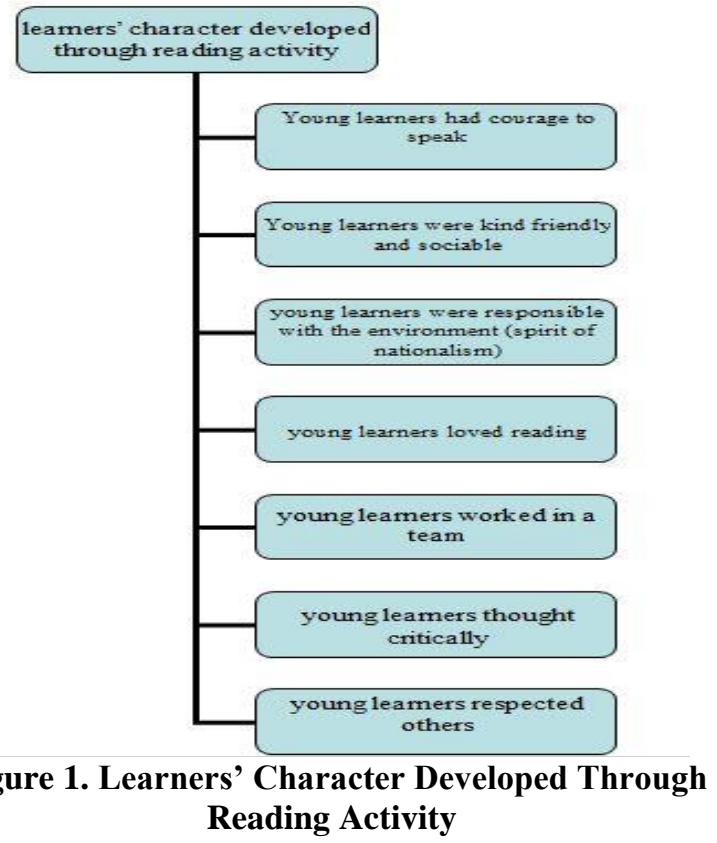

\subsection{Young Learners Had Courage To Speak}

It was found that in implementing dialogic reading, two-way communication between teachers and young learners occurred. Young learners were stimulated to answer or respond teachers' question or comment through the strategies used by teacher "PEER" and "CROWD". Jannah Said "... I say it loud I know the answer". Adhar added "... because Ms. Lala Asked”.

The observation also showed that the PEER and CROWD strategies used by the teacher stimulated the children to speak. The teacher asked the learners "what is this?" then the learners gave various responses. Some of them spoke in English and few of them spoke in Bahasa. Furthermore, in order to encourage learners to speak, the teacher did not only ask short questions, but the teacher also asked long question where the student was hoped to give explanation such as "what happened to the people near the river?" learners were very noisy the first time teacher gave this question. It can be seen that they were engaged with the story. In order to make it effective teacher asked learners to raise their hands before answering, so that everybody could listen.

Dialogic reading encourages children to talk, so that there will be interactive dialogue between teachers and children (Napoli and Johnson, 2019). Therefore, the prompt by teacher facilitates and motivates the young learners to speak up.

\subsection{Young Learners Were Friendly And Sociable}

From the observation it was found that the dialogic reading helped learners to socialize and interact to each other through language. They shared ideas and questions among their peers. They made friends easily. As Adhar said "I tell him he is my friend...". Jannah added "...he does not know which one is trash.. so I help him".

Learners need partners to express their ideas and curiosity. When they can use the language to communicate, it will make them easier to socialize. Study states that language is a tool for communicating and thinking, where young learners can socialize or make friends in learning activities. Through dialogic reading young learners can practice their language and ability to communicate, think and socialize. It is also supported by Studies which found that character education is facilitated in the literature such as kindness, tolerance, etc .

\subsection{Young Learners Were Responsible With The Environment (Spirit Of Nationalism)}

The book used in this study containing value and message to keep the environment clean. The story helped young learners to connect the simple message in the reading activity with their daily life, such as clean the bedroom, sweep the floor, mow the lawn in the backyard, etc. Reading activity was done in 5 meetings using the same story.

The observation showed that every meeting teacher asked young learners what did they do at home, and it 
was found that young learners succeeded in absorbing the messages in the reading activity. They helped their mother to clean the house and backyard. As Riza said "... yesterday, I asked My father to help me cut the grass, and I pick up the plastic waste"

Reading character themed books help young learners to build strong character.

\subsection{Young Learners Loved Reading}

It was found that on the third meeting a young learner brought a new book and asked the teacher to read it. Moreover, the young learners had a long discussion that they went to bookstore to buy a comic in bahasa Indonesia. As said by Jannah “... I and my mother went to Lembuswana to buy a comic book". Adhar added "...I asked mom to buy me a comic".

Love reading is one of the characters that should be shaped in learners. The teacher can expose learners with shared reading activity and make learners get used to it. This activity can shape learners' interest in reading and literacy. Moreover reading books that contain character theme to young learners motivate them to read by themselves.

\subsection{Young Learners Worked In A Team}

The reading activity was done in few stages pre reading activity, reading activity, and follow up activity. In the follow up activity young learners worked together in making poster. As said by Riza "Mala colored the papers, Nanda stacked the pictures and I wrote 'do not litter here!' on the poster".

working in a team helped learners to communicate, get socialize and solve the problem. This skill is very important because learners need it in their real life. Making poster as a follow up of reading activity benefit the learners to improve their social skills and problemsolving skills.

\subsection{Young Learners Thought Critically}

Young learners were asked by teacher and they answered the question as said by the teacher "what is this.... Look at the picture What does a shovel do!" student looked at the picture and tried to understand what was shovel by guessing the picture.

In dialogic reading teacher provide learners with questions where the learners can make connections between the stories and their real life. Furthermore Communication strategies used by teachers encourage young learners to think in the process of reading activity which make the reading activities more effective.

\subsection{Young Learners Respected Others}

It was found from the observation that young learners respected others in the reading activity. In the reading activity using dialogic reading young learners listened to their teacher's questions and clarification. Teacher gave questions to young learners using "PEER" and "CROWD" strategies. Therefore, young learners listened to their teacher questions, clarification and peers' ideas as well. Moreover young learners also listened to their peers when they shared their ideas during the reading activity. Study states that literacy help learners to shape characters including respect (Almerico, 2014).

\section{CONCLUSION}

The study found that the implementation of dialogic reading in reading activity helped young learners to develop their characters such as, young learners have courage to speak, young learners are friendly and sociable, young learners are responsible with the environment (spirit of nationalism), young learners love reading, young learners work in a team, young learners think critically and young learners respect others. It is in line with the previous study which found that literacy facilitated learners to shape their characters through the activity (Almerico, 2014).

\section{SUGGESTION}

Due to the limited subjects in this study, this study could not be done in quantitatively and the result of this study could not be generalized. Therefore, this study only found the learners' characters developed through reading activity using dialogic reading. It is hoped that the next study would be able to implement dialogic reading to some groups of students and would find the significant relationship between the learners' motivation in reading local based literature and their perception toward character building awareness.

\section{REFERENCES}

Almerico, G. M. (2014) 'Building Character through Literacy with Children's Literature', Research in Higher Education Journal, 26.

Creswell, J. W. (2014) Research Design Qualitative, Quantitative and Mixed Methods Approaches. 4th edn. California: Sage.

Farzaneh, N. and Nejadansari, D. (2014) 'Students' attitude towards using cooperative learning for teaching reading comprehension', Theory and Practice in Language Studies, 4(2), pp. 287-292. doi: 10.4304/tpls.4.2.287-292.

Lisa A. Guion, David C. Diehl, and D. M. (2011) 'Triangulation: Establishing the Validity of Qualitative Studies', in University of Florida, pp. 1-3. doi: 10.32473/edis-fy394-2002.

Lonigan CJ, Purpura DJ, Wilson SB, Walker PM, C. J. (2013) 'Evaluating the components of an emergent literacy intervention for preschool children at risk for reading difficulties', Journal of experimental child psychology, 114(1), p. 111-130.

Nanda, D. W. and Azmy, K. (2020) 'poor reading comprehension issue in efl classroom among indonesian secondary school students: Scrutinizing the causes, impacts and possible solutions', Englisia: Journal of Language, Education, and 
Humanities, 8(1), p. 12. doi: 10.22373/ej.v8i1.6771.

Napoli, A. R. and Johnson, V. J. (2019) 'NebGuide', Nebraska Extension Publication, pp. 1-5.

Nugrahanto, S. and Zuchdi, D. (2019) 'Indonesia PISA Result and Impact on The Reading Learning Program in Indonesia', 297(Icille 2018), pp. 373377. doi: 10.2991/icille-18.2019.77.

Ping, M. T. (2014) 'Group interactions in dialogic book reading activities as a language learning context in preschool', Learning, Culture and Social Interaction, 3(2), pp. 146-158. doi: 10.1016/j.lcsi.2014.03.001.

Sim, S. and Berthelsen, D. (2014) 'Shared book reading by parents with young children: Evidence-based practice', Australasian Journal of Early Childhood, 39(1), pp. 50-55. doi: $10.1177 / 183693911403900107$.
You, Y. (2011) 'Factors in Vocabulary Acquisition through Reading', Itj, 8(1), pp. 43-57. 